\title{
EKSISTENSI DAN FUNGSI DOANGANG PADA KEHIDUPAN SOSIAL ORANG MAKASSAR
}

\author{
THE EXISTENCE AND FUNCTION OF DOANGANG \\ IN SOCIAL LIFE OF MAKASSAR COMMUNITY
}

\author{
Nur Alam Saleh \\ Balai Pelestarian Nilai Budaya Sulawesi Selatan \\ Jln. Sultan Alauddin/Tala Salapang KM.7 Makassar \\ salehnuralam@gmail.com
}

Diterima tanggal 12 Januari 2019

Disetujui tanggal 12 Juni 2019

\begin{abstract}
The study explained about doangang or spell which is the local wisdom and a part of culture of Makassar people. Spell is a type of spoken literature in the form of poetry which has structure. The existence of medicinal spell was influenced by community's belief. The objectives of this study were to find out the form and function of doangang in Makassar's social and cultural life and community's point of view, as well as to examine several values of the spell, either main spell or utterance (supporting) referring to the users. The study was conducted in one of regions in Tombolo village of Sombaopu subdistrict, Gowa district. The study employed qualitative research using descriptive type. The techniques of data collection were field observation, documentation and interview. Furthermore, techniques of data analysis were data reduction, data presentation, and conclusion.
\end{abstract}

Keywords: doangang, spell, power, heritage, and culture.

\begin{abstract}
ABSTRAK
Penelitian ini menjelaskan tentang doangang atau mantra yang merupakan sebuah kearifan lokal dan sebagai bagian dari budaya orang-orang Makassar. Mantra merupakan jenis sastra lisan yang berbentuk puisi memiliki struktur. Keberadaan mantra pengobatan dipengaruhi oleh kepercayaan masyarakat. Tujuan penelitian untuk mengetahui bentuk dan fungsi doangang dalam kehidupan sosial budaya Makassar dan pandangan masyarakat terhadap keberadaan doangang yang ternyata mampu memberi dan menerima pengaruh pada masyarakat serta dengan menggali berbagai nilai yang terkandung di dalamnya, baik yang bersifat utama maupun tuturan (sampingan) yang mengacu pada masyarakat penggunanya. Penelitian dilakukan pada salah satu daerah di Makassar yaitu di Kelurahan Tombolo, Kecamatan Sombaopu, Kabupaten Gowa. Penelitian ini menggunakan jenis penelitian kualitatif dengan tipe deskriptif. Teknik pengumpulan data diperoleh dengan penelitian lapangan yang mencakup observasi, dokumentasi, dan wawancara. Adapun teknik analisis data yaitu reduksi data, penyajian data, dan penarikan kesimpulan.
\end{abstract}

Kata kunci: doangang, mantra, kekuatan, warisan, dan kebudayaan. 
Handep, Vol. 2, No. 2, Juni 2019

\section{A. PENDAHULUAN}

Masyarakat Indonesia telah mengenal mantra sejak dulu. Mantra dikenal masyarakat Indonesia sebagai rapalan "ucapan dalam bahasa tertentu" untuk maksud dan tujuan tertentu (maksud baik maupun maksud tidak baik). Mantra merupakan puisi lisan yang bersifat magis. Magis berarti sesuatu yang dipakai manusia untuk mencapai tujuannya dengan cara-cara yang istimewa. Perilaku magis disebut sebagai pelaku yang dilakukan untuk mencapai suatu maksud tertentu yang dipercaya manusia ada di alam supranatural (Rusyana, 1970: 3).

Mantra merupakan sastra daerah yang berfungsi sebagai sarana pengungkap tata nilai sosial budaya dan kehidupan daerah. Karena itu, lewat pengungkapan doangang kita dapat menggali berbagai nilai yang terkandung di dalamnya, baik yang bersifat utama maupun tuturan (sampingan) yang mengacu pada masyarakat penggunanya. Bahkan lewat pengungkapan mantra dapat menggali nilai budaya yang lebih dalam dan luas lagi, yaitu sampai pada kepercayaan dan kebergunaan.

Dalam antropologi, istilah mantra biasa dikenal dengan magis (ilmu gaib). Lebih lanjut Richard dalam Suyasa (2004: 2) mengatakan bahwa mantra sebagai ekspresi manusia yang diyakini mampu mengubah suatu kondisi karena dapat memunculkan kekuatan gaib, estetik, dan penuh mistis.

Schmidt dalam Ismail (1996: 2) mengatakan bahwa manusia pada masa kehidupan primitif telah memiliki kepercayaan monoteisme. Akan tetapi, setelah kehidupannya berkembang kepercayaan kepada Tuhan menjadi rusak. Sementara itu, Lubbock dalam Ismail (1966: 2) memandang bahwa bangsa primitif tidak memiliki agama (ateis). Ateisme berturut-turut berkembang menjadi retitisme, manusia dapat memaksa dewa agar memenuhi tuntutannya melalui mantra-mantra. Jika kedua pendapat ini dikaitkan dengan pendapat Frazer dalam Polak (1986) yang memandang manusia dalam dirinya memiliki kepercayaan kepada hal-hal yang gaib dan memiliki perilaku yang bersifat religius, maka mantra merupakan kajian yang menarik untuk diungkapkan. Apalagi dalam masyarakat Makassar yang sebagian besar masih mengenal mantra dalam berbagai fungsi (Yatim, 1983: 31).

Kehadiran mantra berpangkal pada kepercayaan masyarakat pendukung. Sejumlah penilaian, sikap, dan perlakuan masyarakat terhadap mantra semakin berkembang. Masyarakat ada yang percaya penuh dan ada yang hanya percaya sebagian terhadap mantra dalam kepentingan hidupnya. Sebagian masyarakat lainnya secara langsung atau tidak langsung menolak kehadiran mantra dengan pertimbangan bahwa menerima mantra berarti melakukan perbuatan syirik. Pada masyarakat yang disebutkan pertama dapat digolongkan ke dalam masyarakat penghayat atau pendukung mantra, sedangkan masyarakat yang lainnya digolongkan ke dalam masyarakat 
bukan penghayat mantra.

Pandangan masyarakat terhadap mantra telah memunculkan beberapa pandangan. Bagi masyarakat penghayat mantra, kegiatan sehari-hari kerap kali diwarnai dengan pembacaan mantra demi keberhasilan dalam mencapai maksud, misalnya, para petani ingin sawahnya subur, terhindar dari gangguan hama, jika panen tiba hasilnya melimpah, para pedagang ingin dagangannya laris, dan pengharapan lainnya.

Penggunaan mantra di masyarakat modern saat ini sudah mulai ditinggalkan. Padahal, sebagai tradisi masyarakat yang sudah turun temurun, mantra memiliki nilai kearifan yang perlu digali. Mantra sebagai sastra lisan yang lebih khusus juga sebagai folklor jelas memiliki nilai. Danandjaja dalam Pudentia (2008: 73) mengungkapkan bahwa folklor baik secara terselubung maupun secara gamblang melukiskan cara berpikir pemiliknya. Ketika masyarakat sudah mulai meninggalkan tradisi, tidak dipungkiri sebenarnya masyarakat sudah meninggalkan nilainilai luhur yang dianutnya secara turun temurun. Misalnya kegiatan bertani yaitu adanya penuturan mantra menjadi suatu upaya memohon perlindungan kepada yang kuasa diluar kekuasaan manusia. Hal tersebut menunjukkan adanya kesadaran bahwa manusia memiliki keterbatasan dan memiliki kemampuan untuk berusaha. Oleh karena itu manusia perlu berdoa kepada yang menguasai kehidupan. Perlu ada penelitian mengenai mantra yang ber- tujuan untuk menggali nilai-nilai kearifan dengan harapan dapat diejewantahkan dalam kehidupan masyarakat.

Masyarakat penghayat percaya mantra membawa keberuntungan dengan kekhususan fungsi masingmasing mantra. Mantra juga diterima kehadirannya sebagai warisan nenek moyang yang memiliki nilai bagi masyarakat. Sedangkan bagi masyarakat bukan penghayat mantra, prasangka yang muncul adalah negatif. Hal ini didasarkan atas penilaian masyarakat bukan penghayat yang menegaskan bahwa permohonan sesuatu melalui mantra-mantra adalah perbuatan syirik. Penilaian golongan masyarakat ini lebih tegas lagi pada jenis mantra untuk tujuan jahat yang dikenal dengan magis hitam. Di samping itu, ketidakpercayaan terhadap kekuatan gaib yang terkandung dalam mantra dan adanya persyaratanpersyaratan tertentu misalnya, harus berendam di sungai, dan sebagainya menimbulkan antipati yang cukup kuat.

Kenyataan yang ada mengenai pandangan dan kepercayaan masyarakat pada mantra menarik untuk dibahas. Kehadiran mantra ternyata mampu memberi dan menerima pengaruh kepada masyarakat. Hadirnya ajaran Islam berpengaruh pada isi dan praktik mantra sehingga berpadu, seperti menyertakan kalimat tayibah, syahadat, dan kalamullah lainnya.

Makassar adalah salah satu nama suku yang mendiami daerah Provinsi Sulawesi Selatan. Suku Makassar 
mempunyai sastra daerah yang cukup banyak. Sebagaimana halnya sastra daerah pada umumnya, sebagian besar sastra Makassar adalah sastra lisan. Upaya mengembangkan dan memperkaya, khazanah kesusastraan daerah perlu dilakukan terus menerus. Salah satu dari sekian banyak sastra lisan Makassar yang akan menjadi objek penelitian ini adalah doangang, yaitu sejenis mantra.

Sastra lisan Makassar adalah bagian dari sastra tradisional di Indonesia. Pernyataan ini sejalan dengan pendapat Robson dalam Nasruddin (1987: 1) yang menyatakan bahwa tidak ada sastra tradisional dalam bahasa Indonesia, yang ada Bahasa Melayu dan bahasa daerah lainnya. Sastra lisan Makassar sebagian telah berkembang dalam visi modern tetapi ciri bentuk tradisional tetap di pertahankan, Hingga saat ini masyarakat yang berlatar belakang budaya dan bahasa Makassar tetap mengenal eksistensi sastra lisan Makassar, sebagaimana karya sastra lainnya, ia mencerminkan berbagai gambaran kehidupan masyarakat (Darmono, 1987: 1) baik secara manifes maupun secara tersembunyi, yang memerlukan satu upaya serius untuk mengungkapkan fungsi apa dan latar belakang yang mendasarinya.

Doangang atau mantra merupakan sebuah kearifan lokal budaya suku Makassar. Doangang dapat memberikan gambaran luas tentang pola dan macam kehidupan masyarakat pendukungnya. Sebagai bagian dari budaya mantra merupakan suatu keberhasilan karya sastra yang harus diwariskan dari generasi ke generasi.

Dalam konteks itu, maka penulisan tentang "Eksistensi dan Fungsi Doangang Orang Makassar di Kabupaten Gowa" dengan fokus masalah sebagai berikut : 1) bagaimana bentuk dan fungsi doangang dalam kehidupan orang Makassar di Kelurahan Tombolo, Kecamatan Sombaopu, Kabupaten Gowa; 2) bagaimana pandangan masyarakat terhadap keberadaan doangang orang Makassar di Kelurahan Tombolo Kecamatan Sombaopu Kabupaten Gowa.

\section{B. METODE}

Metode yang digunakan penelitian ini adalah metode deskriptif kualitatif. Penelitian kualitatif adalah penelitian yang bersifat uraian yang tidak bisa diubah ke dalam bentuk angka-angka. Bogdan dan Taylor (Moleong, 2010: 4), mendefinisikan bahwa penelitian kualitatif sebagai prosedur yang menghasilkan data deskriptif berupa kata-kata yang tertulis atau lisan orang lain dan perilaku yang dapat diamati. Penelitian kualitatif juga menghasilkan data deskriptif yaitu metode yang bersifat memaparkan gambaran yang secermat mungkin mengenai individu, keadaan bahasa, gejala atau kelompok tertentu. Moleong (2010: 11) menyatakan bahwa data yang dikumpulkan dalam metode deskriptif adalah berupa kata-kata, gambar, dan bukan angka-angka. 
Data pada penelitian ini dibagi atas dua, yakni data primer dan data sekunder. Data primer diperoleh dari pengamatan (observasi) langsung di lapangan dan wawancara mendalam (indept interview). Untuk pengamatan digunakan teknik ber-peran serta, yakni memasuki wilayah penelitian untuk mengungkap data hingga mendetail (Endaswara, 2006; Moleong, 2010). Sedangkan wawancara mendalam atau wawancara etnografi, meminjam istilah Endaswara (2006), dilakukan dengan santai dan informal sehingga ada keterbukaan antara peneliti dan diteliti. Ini dimaksudkan agar orang yang diwawancarai tidak merasa sedang diwawancarai (Moleng, 2010).

\section{C . HASIL DAN BAHASAN}

\section{Latar Belakang Sosial Budaya Orang Makassar}

Tombolo merupakan salah satu dari 14 kelurahan yang ada dalam wilayah Kecamatan Sombaopu berjarak sekitar $5 \mathrm{Km}$ dari pusat pemerintahan Kabupaten Gowa. Kelurahan Tombolo, terbagi atas dua lingkungan yakni lingkungan Tombolo dan Pa'bangngiang, dengan penduduk sebanyak 11.578 jiwa. Laki-laki sebanyak 5.754 jiwa dan perempuan 5.824 jiwa.

Kehidupan masyarakat Kelurahan Tombolo mayoritas bermata pencaharian utama sebagai tukang atau buruh bangunan. Disamping itu ada juga yang berstatus sebagai karyawan swasta, PNS, TNI, dan Polri. Adat istiadat masyarakat tentang mantra masih kuat. Sebagian masyarakat masih percaya dengan mantra dan kegunaannya. Mantra yang masih dipercaya dan dipraktikkan di masyarakat antara lain mantra untuk pengobatan, mantra untuk pakaian atau pelindung diri, mantra untuk pekerjaan, dan mantra untuk adat istiadat.

Secara umum masyarakat Makassar menganut agama Islam (Yatim, 1983: 31). Demikian halnya dengan masyarakat Kelurahan Tombolo. Mereka menganut agama Islam secara taat dalam arti kepercayaan. Artinya orang Makassar meski tidak melakukan sembahyang dan puasa secara penuh, mereka tidak mau dikatakan bukan Islam. Orang Makassar seperti itu lebih banyak menjadikan Islam dalam hatinya dan dalam pikirannya. Mereka senantiasa memikirkan Islam, tetapi ibadat-ibadat dalam rukun Islam tidak atau sukar dilakukannya secara sempurna. Jawaban atas pertanyaan kepada mereka, spontan marah bila dikatakan bukan Islam atau kafir dan mereka ingin dikuburkan di pekuburan Islam. Sama halnya kalau dikatakan Islam sossorang (Islam keturunan), tidak akan diakuinya, karena mereka mengucapkan dua kalimat syahadat sebagai pengukuhan dirinya saat sunatan dan akad nikah.

Upacara keislaman yang sering dilakukan adalah upacara daur hidup anggota keluarga, upacara Maulid dan Mi'raj. Dalam upacara daur hidup anggota keluarga seperti kelahiran, sunat, perkawinan, dan kematian, 
diiringi dengan pembacaan barasanji (syair-syair riwayat hidup Nabi Muhammad SAW yang disusun oleh Syekh Ja'far al-Barzanji bin Hasan bin Abdul Karim).

Ketika upacara-upacara tertentu, seperti meminang gadis, menamai anak (tasmaniah), dan khatam Alquran sering dilantunkan puisi, pantun, syair, dan prosa yang dibawakan orang-orang yang dituakan. Bahkan kerapkali dibacakan doangang dengan suara tidak keras. Pembacaan doangang dimaksudkan untuk memeriahkan segala upacara dengan harapan terselenggara dengan lancar tanpa halangan.

Pada mulanya masyarakat Makassar menganut kepercayaan animisme dan dinamisme. Mereka mengakui dan percaya kekuatan alam atas dan alam bawah. Sehubungan dengan hal itu pula, tradisi keagamaan yang berkembang dalam masyarakat Makassar selain kepercayaan lama yang bersumber dari nenek moyang juga kepercayaan yang bersumber dari Islam. Kedua sumber kepercayaan itu berbaur dalam pelaksanaan praktik upacara-upacara.

Hamid (1994: 47) membagi tiga aspek kepercayaan lama masyarakat Makassar yang bersumber dari tradisi keagamaan nenek moyang, yaitu (1) kepercayaan terhadap arwah nenek moyang (2) kepercayaan kepada dewadewa agama patuntung, dan (3) kepercayaan terhadap arwah nenek moyang dinyatakan dengan pemujaan terhadap. (a) tempat dan benda-benda tertentu, dan (b) kuburan, pemujaan terhadap tempat dan benda-benda tertentu, misalnya batu naparak (batu latar), pohon kayu besar, gunung, sungai dan tanah.

Pemujaan terhadap kuburan yang dipahami memiliki sejarah tertentu, yaitu kuburan orang yang berjasa membangun pemukiman dan memberi keselamatan, kuburan orang-orang suci (ulama) dan wali. Kuburan tersebut dianggap keramat. Begitu juga tempat dan benda-benda yang dipuja dipercaya memiliki kekuatan. Arwah nenek moyang dipercaya selalu mengawasi keturunannya dan memberi keselamatan di dunia dan di akhirat. Relasi yang harmonis perlu dijaga dengan mengadakan ritual dan sesajian. Pelaksanaan upacara-upacara yang berhubungan dengan tempat sakral dipimpin seorang pinati (ahli).

Masyarakat Makassar yang percaya dengan dewa-dewa agama patuntung mengakui adanya dewa tertinggi yaitu Tukammaya Kananna, dewa yang menciptakan semua dan seluruh isi alam. Dewa pengawas dan pemelihara alam disebut Appatanna. Sedangkan dewa yang menjaga bumi ini disebut Ratanna Lino. Pemujaan kepada dewa-dewa patuntung dipimpin oleh seorang tokoh yang disebut Anrongguru. Pusat patuntung bersemayam di puncak Gunung Bawakaraeng. Namun, upacara bisa saja dilakukan di kampung sendiri.

Ajaran patuntung mempercayai adanya ruang Loketa yakni dewa-dewa bawahan yang berada di semua tempat dan bertugas menggerakkan peristiwa alam. Pada umumya upacara hanya 
ditunjukkan kepada Puang Loheta untuk memohon perlindungan dari malapetaka tertentu, seperti perlindungan dari penyakit menular, pembasmian hama tanaman, dan sebagainya. Dalam keadaan luar biasa, orang membuat upacara langsung memohon kepada dewa tertinggi, Tukammaya Kananna, seperti minta hujan dan keselamatan seisi kampung.

Aspek kepercayaan terhadap persona-persona jahat dalam masyarakat Makassar dikenal dengan nama parakang, poppo, dan tujua. Persona jahat dipercaya bisa mendatangkan penyakit dan kematian. Persona-persona bisa datang dari seseorang yang memanipulasi kekuatan rohaninya menjadi bentuk tertentu untuk dapat mengganggu korbannya. Bisa pula berupa kekuatan magis dan semacamnya yang telah dimanipulasi oleh seseorang yang punya maksud tertentu pada orang lain. Orang yang menjadi persona jahat adalah orang yang memiliki suatu ilmu yang telah dipelajari dari gurunya. Ada kalanya dialihkan dari orang tuanya kepada anaknya yang menghendaki ilmu tersebut.

Agama Islam diterima secara resmi di Kerajaan Gowa dan Tallo pada bulan 9 Jumadil Awal 1014 Hijriah atau tanggal 22 September 1603 (Yatim, 1983: 49). Penerimaan agama Islam sebagai agama kerajaan di Gowa dan Tallo membuat kerajaan-kerajaan kecil di sekitar Sulawesi Selatan mengikutinya sehingga rakyatnya ikut menganut agama Islam. Kondisi tersebut membawa perubahan dalam pem- baharuan ajaran Islam yang dilaksanakan oleh seorang ulama besar, sufi, dan pejuang Syekh Yusuf Tuanta Salamaka.

Kehadiran ulama besar itu mengubah perilaku atau kebiasaan masyarakat Makassar minum-minuman keras yang disebut Ballok Asrruk, memuja pantasak dari saukang (bendabenda yang dikeramatkan) serta perjudian assaung (menyabung ayam). Tidak sedikit pula masyarakat Makassar yang mempelajari ilmu-ilmu mantra sesuai dengan keinginannya masingmasing.

Masyarakat Makassar mengenal ada dua macam kekuatan magis yatu magis putih dan magis hitam. Ilmu magis putih dimiliki oleh sebagian ulama, dukun untuk mengobati dan menyembuhkan segala macam penyakit yang datang. Penyakit itu berasal dari magis hitam yang disebut paccak, doti. Dengan magis hitam, orang dapat dibuat sakit-sakitan, tidak sadar, gila, tubuhnya banyak tumbuh benjolanbenjolan, dan berbagai macam penyakit lainnya. Bila tidak dilakukan pengobatan sedini mungkin, penderita perlahan akan mati atau menderita sakit berkepanjangan. Fungsi doangang bisa untuk menyembuhkan segala macam penyakit melalui salah seorang ulama atau dukun.

\section{Deskripsi Fungsi Doangang (Mantra) Orang Makassar}

Mantra bagi orang Makassar dikenal dengan sebutan doangang yang berarti permohonan, permintaan, dan 
harapan. Sama dengan mantra versi Melayu, doangang juga diyakini memiliki berkah dan mengandung kesaktian atau kekuatan gaib, apalagi bagi orang yang berhasil mendalaminya. Hampir setiap aktivitas orang Makassar pada masa lampau bahkan hingga kini didahului dengan membaca doangang dengan harapan agar mereka mendapatkan keselamatan.

Pengguna doangang perlu memperhatikan beberapa syarat untuk mendapatkan berkah Allah SWT. Antara lain; tidak boleh terlalu membanggakan atau menyombongkan diri; tidak boleh mengucapkannya di sembarang waktu dan tempat; harus yakin bahwa doangang yang diucapkan itu mempunyai daya gaib; serta hanya dipakai dengan maksud untuk membela diri atau untuk menolong orang lain.

Doangang biasanya diberikan oleh tetua adat, sanro atau orang-orang yang dituakan dalam masyarakat Makassar. Doangang diterima sebagai kebutuhan penunjang setelah kehidupan agamanya telah dijalani secara sungguh-sungguh. Adanya kebutuhan terhadap doangang menjadi warna yang menghiasi kehidupan sehari-hari. Kegiatan yang tidak terlepas dari keadaan alam dan mata pencahariaan, sehingga menghasilkan tiga kelompok besar sehubungan dengan penggunaan doangang, yaitu doangang yang digunakan untuk perlindungan, kekuatan, dan pengobatan.

Berdasarkan hasil informasi melalui wawancara dari sejumlah informan di lapangan, maka berikut ini dikemukakan beberapa doangang yang digunakan sebagai perlindungan, kekuatan dan pengobatan beserta fungsinya.

\section{Doangang yang Terkait Dengan Perlindungan}

Doangang yang terkait dengan perlindungan atau keamanan umumnya menyangkut keamanan rumah dan kebun. Kedua tempat ini amat diperhatikan bahkan diprioritaskan pengamanannya selain tempat lainnya. Hal ini dilakukan karena rumah dijadikan tempat perlindungan utama dan kebun digunakan sebagai salah satu tempat mata pencaharian.

\section{a. Mendiami Rumah Baru (Antamak Ballak)}

Setiap orang menginginkan tempat tinggal (rumah) yang layak untuk menjalani hidup. Apabila keinginan itu terkabulkan dalam masyarakat Makassar, rumah baru tidak langsung di huni. Melainkan, setiap rumah baru harus terlebih dahulu diselamati. Salah satu cara dalam selamatan bisa dengan membaca doangang. Doangang yang biasa digunakan untuk mendiami rumah baru diistilahkan antamak ballak adalah sebagai berikut.

\section{Allahumma Sholli Ala Muhammad Terjemahannya: \\ Ya Allah, berikanlah keselamatan kepada Nabi Muhammad}

Fungsi doangang tersebut adalah untuk menjaga rumah agar supaya tidak ditempati mahluk-mahluk halus atau semacamnya; supaya penghuni rumah 
menjadi rukun, damai, dan tentram selalu.

Adapun tata caranya, yakni dengan membaca doangang sebanyak tiga kali secara berulang. Kemudian menulis doangang tersebut sebanyak empat lembar dan ditempelkan pada tiap-tiap sudut rumah (satu sudut satu orang). Selanjutnya mengumandangkan azan dan ikamah dengan posisi berdiri. Lalu sembahyang magrib berjamaah berzikir dan berdoa bersama. Berlanjut pembacaan surah Yasin sebanyak 3 kali.

\section{b. Menjaga Rumah (Pajaga Ballak)}

Disamping ada doangang yang digunakan untuk mendiami rumah baru, orang Makassar juga menggunakan doangang untuk menjaga rumah supaya aman dan menghindari niat jahat terhadap rumah, isinya dan penghuninya. Isi doangang untuk menjaga rumah yang istilah bahasa Makassar-nya, pajaga ballak, adalah sebagai berikut.

\section{Bismillahirrahmannirahim \\ Ikau palukkak bangia \\ Katutuimami tubunu \\ Katutui tallasaknu}

Numammempomo ri ballaknu Numanngukrangi

Ri Sahada mula taunnu

Barakkak La ilaha Illalah

Terjemahannya :

Dengan Nama Allah Yang Maha

Pengasih Lagi Maha Penyayang

Wahai kamu penggarong malam

Pelihara tubuhmu

Jaga kehidupanmu

Duduklah dirumahmu

Untuk merenung

Pada penyaksian awal lahirmu

Berkat La Ilaha Illalah
Fungsi doangang di atas adalah untuk menjaga rumah supaya tidak kemasukan pencuri atau perampok sehingga penghuninya dapat tinggal atau tidur dengan tenteram dalam rumah. Doangang pajaga ballak dibaca minimal tiga kali kemudian tiupkan ke lubang kunci pintu. Kalau pintu rumah ada dua (di muka dan di belakang), maka bacakan doangang tersebut pada tiap-tiap lubang kunci pintu. Waktu pelaksanaan doangang ini terutama pada saat kita hendak tidur pada malam hari.

\section{c. Menjaga Kebun (Pajaga Koko)}

Kebun merupakan salah satu tempat mata pencaharian masyarakat. Masyarakat menanam berbagai jenis tanaman yang dapat dijual sehingga dapat memperoleh uang. Tanaman yang sering di tanam di kebun berupa buahbuahan seperti jeruk, pisang, mangga, durian, pepaya, dan kelapa.

Keamanan kebun sangat perlu agar terhindar dari pencurian. Pencurian hasil kebun menjadi masalah yang merugikan masyarakat. Adapun doangang untuk melindungi dan menjaga kebun atau dalam bahasa Makassar disebut pajaga koko sebagai berikut.

\section{Bismillahirrahmanirahim}

Wajaalna min baini aidihim

Saadam fa-aghsyainaa hum

Fahum laa yubshirum

Barakkak La Ilaha Illalah

Muhammadarrasulullah.

Terjemahannya:

Dengan Nama Allah Yang Maha

Pengasih Lagi Maha Penyayang 
Dan kami telah menjadikan penghalang

Di hadapan dan di belakang mereka Juga kami menutup pemandangan mereka

Sehingga mereka tidak dapat melihat Berkat tiada Tuhan, melainkan Allah

Muhammad pesuruh Allah.

Fungsi doangang di atas adalah untuk menjaga keamanan kebun dari gangguan pencuri atau perampok. Caranya adalah menyediakan air putih secukupnya, membaca surah Yasin sebanyak tiga kali, lalu meniupkannya pada air putih yang telah disediakan sebanyak tiga kali.

Setelah itu, memercikkan air putih yang sudah diberi doangang. Waktu yang baik untuk membaca surah Yasin yaitu malam Jumat. Dilanjutkan memercikkan air dan membaca doangang pada hari Jumat pagi sebelum matahari terbit.

\section{d. Menjaga Diri dari Pesona-Pesona Jahat}

Orang Makassar percaya adanya pesona-pesona jahat yang membawa penyakit maupun kematian. Alhasil banyak orang yang takut terkena pesona jahat. Pesona-pesona jahat datang dari seseorang yang memanipulasi kekuatan magis untuk mengganggu korbannya.

Pesona-pesona jahat yang sangat ditakuti adalah parakang, poppo, dan tujua. Pesona-pesona jahat dipercaya bisa memakan serta menyedot organ tubuh bagian dalam seperti hati, jantung, dan usus. Parakang, poppo, dan tujua dapat berwujud binatang misalnya kerbau, kucing, anjing, burung, bisa pula menjadi keranjang yang bergerak pada malam hari.

Salah satu cara yang biasa dilakukan dan dianggap cukup mampu menghalau pesona-pesona jahat adalah dengan membaca doangang seperti berikut.

\section{Bismillahirrahmannirahim Subhanallah \\ Walhamdulillah \\ Walailaha illallah \\ Terjemahannya :}

Dengan menyebut nama Allah yang

Maha Pengasih lagi Maha Penyayang

Maha Suci Allah

Segala Puji Bagi Allah

Tiada Tuhan Selain Allah

Doangang di atas berguna agar pesona-pesona jahat itu tidak mengganggu ketenteraman manusia. Cara pelaksanaannya yakni ketika keluar malam dan melihat sesuatu yang aneh sampai berdiri bulu roma, janganlah diganggu atau biarkanlah. Akan tetapi, bila merasa ada yang mengikuti dan merasa berada dalam siuasi yang berbahaya maka perlu membaca doangang sebanyak tiga kali. Dilanjutkan membaca surah Al-Fatihah sebanyak-banyaknya secara berulangulang.

Ketika mendengar suara binatang yang aneh saat berada dalam rumah pada malam hari maka membaca doangang minimal tiga kali. Lalu dilanjutkan surah Al Fatihah sebanyak banyaknya sampai suara itu menghilang. 


\section{e. Terhindar dari Gangguan Orang}

Ketika berada di suatu wilayah atau jalan yang rawan bahaya maupun gangguan dari orang sehingga membuat takut ataupun terancam, orang Makassar mempunyai doangang guna perlindungan diri. Di bawah ini adalah bunyi doangan tersebut:

\section{Bismillahirrahmanirrahim}

Punna naunga ri butta

Kukangkang cahayana lino Kusukang bunga ri ia Sikuntu mahalloka

Maccini manngaingaseng

Mange ri nakke

Barakkak la illaha illalah

Terjemahannya :

Dengan menyebut nama Allah yang

Maha Pengasih lagi Maha Penyayang

Kalau aku keluar rumah

Kugenggam cahaya alam

Kuangkat bunga padanya

Semua makhluk

Melihat menyukai semua Kepada saya

Berkat La Illaha Illalah

Fungsi doangang di atas agar selamat dan terhindar dari gangguan orang-orang usil, brutal, atau nakal. Meskipun harus bertemu dan melewati mereka yang sedang berkelompok pada suatu jalan atau gang yang mereka kuasai.

Doangang dibaca sebanyak tiga kali sebelum melewati jalan, gang, atau tempat yang rawan bahaya. Kemudian meni-upkannya sebanyak tiga kali ke arah orang atau kelompok yang diduga akan mencelakai. Meskipun agak berjauhan, anggaplah tiupan itu mengenai orang-orang yang dituju.
Waktu melakukan jangan terlalu kentara. Lakukan sambil berjalan seperti biasa sambil sekali-kali tersenyum kepada orang-orang yang kita lewati.

\section{Doangang yang Terkait Dengan Kekuatan}

Doangang ini lebih dominan digunakan oleh kaum laki-laki. Bukan sebagai aksi gagah-gagahan tetapi sebagai suatu amalan yang digunakan untuk jaga diri ketika menghadapi orang yang berbuat jahat.

\section{a. Ilmu Kebal Senjata}

Orang Makassar banyak yang minat soal kebal senjata. Kekuatan kekebalan senjata bisa digunakan untuk kejahatan atau kebaikan. Orang-orang Makassar da-hulu bisa kebal terhadap senjata yang umumnya hanya digunakan untuk keperluan mendesak atau terjepit. Doangang yang berkaitan dengan kekebalan dapat dituturkan sebagai berikut ini;

Bismillahirrahmanirrahim
Assalamu Alaikum
Ikiramang ri kairingku
Katibina ri kanangku
Yakmaluna ri bokoku
Matapaaluna ri dallekangku
Ilalangminne rantena nyawaya
Balangguna tubua
Mangngapa taniapaya
Makgauk tanigaukia
Tanilaloa bokona
Tanipolong dallekanna
Anrong gurunna maksakraya
Karaenna maksaraya
Karaenna makkanaya


Handep, Vol. 2, No. 2, Juni 2019

Silamaka nammatung

Sisingkuluka naksara talang

Barakka La Ilaha Illallah

Terjemahannya;

Dengan nama Allah yang Maha

Pengasih lagi Maha Penyayang

Ikiramang di samping kiriku

Katibina di samping kananku

Yakmalun di belakangku

Matapaaluna di depanku

Sudah terpatri di dalam sukmamu

Bentengnya tubuhku

Berbuat tak disanggah

Bertindak tak ditindaki

Tak terlewati belakangnya

Tak terlalui di hadapannya

Pemimpin segala yang bersuara

Raja bagi semua yang berkata

Baru sejengkal sudah melenting

Sehasta berbunyi talang

Berkat la ilaha illallah

Fungsi doangang di atas untuk menghindarkan diri dari luka atau tembus tusukan maupun tembakan senjata api. Apabila sedang menghadapi musuh yang membawa senjata berupa badik, keris, pisau golok bahkan senjata api sekalipun, maka doangang dibaca secara berulang-ulang minimal tiga kali. Setelah dibaca, perlu menahan nafas dan membaca tambahan doangang berikut ini sebanyak satu kali:

Bismillahirrahmanirrahim

Gassa assingku

Ammalak cerakku

Bassi kalling bukkulengku

Batunaparak ilalang

Kupakeminne ranrang tamatappukna

Gowa

Samparaja tasappea

Benteng tatippung
Tonasak tamanrakbaya

Kumfayakum

Barakka La Ilaha Illallah

Terjemahannya;

Dengan nama Allah Tuhan Yang

Maha Pengasih Lagi Maha Penyayang

Aluminium dagingku

Membeku darahku

Besi baja kulitku

Batu cadas di dalam

Telah kupakai tali yang takkan putus dari Gowa

Tulang yang takkan patah

Tiang yang tak lapuk

Teras yang takkan goyah Kumfayakum

Berkat La Ilaha Illallah

Pusatkan pada lawan yang dihadapi sembari menatap matanya dan hati harus berpusat kepada Allah SWT. Maksud pembacaan doangang perlu disertai dengan keyakinan dan tawakkal kepada Allah SWT sehingga doangang tersebut ampuh. Orang Makassar mempunyai doangang guna kebal senjata seperti di bawah ini:

Bismillahirrahmanirrahim

Barambang bête-betea

Tonasak batang jambua

Dongkokku dongkok gassa

Bukkulengku bukkuleng takekkek

Tamamminra bukkulengku

Kumpayakum

Barakkak La Ilaha Illallah

Terjemahannya;

Dengan nama Allah Tuhan Yang

Maha Pengasih lagi Maha Penyayang

Dada bete-bete (nama jenis ikan)

Teras batang jambu

Punggungku punggung aluminium

Kulitku kulit takkan robek 
Tak akan berbekas di kulitku Kumfayakum

\section{Berkat La Ilaha Illallah}

Fungsi doangang di atas adalah untuk memperoleh kekebalan atau kekuatan tubuh terhadap serangan senjata atau tembakan senjata api. Untuk memperoleh kekebalan atau kekuatan maka doangang dibaca secara berulang-ulang paling sedikit tiga kali ketika sedang menghadapi lawan yang bersenjata tajam, sembari menatap tajam matanya dan berkonsentrasi kepada Allah SWT.

Pada zaman dahulu doangang ini diyakini ampuh sebagai pengebal tubuh terhadap serangan senjata api. Pemakai doangang tidak pernah takut dalam menghadapi ancaman. Bahkan dengan keyakinannya, pengguna doangang pasrah saja ditusuk atau ditembak.

\section{Doangang yang Berkaitan Dengan Pengobatan}

\section{a. Penyakit Cacar (Pattuik Puru)}

Berbagai macam penyakit dapat menyerang seseorang baik pada anakanak, pemuda, ataupun orang dewasa. Penyakit cacar merupakan penyakit yang umum diderita oleh masyarakat Indonesia. Penyakit ini tidak hanya menyerang orang yang berusia lanjut, berusia remaja (muda), tetapi juga berusia dini atau anak-anak.

Masyarakat Makassar mengenal beberapa jenis penyakit cacar yaitu cacar air, cacar api, cacar lebar (puru buyang). Gejala penyakit yakni panas dingin dan gatal-gatal pada kulit. Orang yang pernah menderita penyakit cacar biasanya membekas pada kulit yang disebut karokbak (bopeng) Dua opsi mengobati yang biasa ditempuh orang Makassar dalam mengobati penyakit cacar yaitu berobat ke dokter atau dukun. Dukun membaca doangang untuk mengobati cacar dengan bacaan seperti berikut:

Bismillahirrahmanirrahim

Bacco I tahara Allah Taala

I tahara Nakbi Muhammad

Barakkak La ilaha Illallah

Barakkak Muhammad ya Rasulullah

Terjemahan :

Dengan nama Allah Tuhan Yang

Pengasih lagi Maha Penyayang

Bacco I tahara Allah Taala

I Tahara Nabi Muhammad

Berkat la Ilaha Illallah

Berkat Muhammad Ya Rasulullah

Cara pelaksanaannya dengan membacanya sebanyak tiga kali di atas segelas air putih. Setelah itu, penderita cacar biasa meminumnya sampai habis. Doangang ini dapat pula dilakukan dengan cara membaca doangang secara berulang-ulang minimal tiga kali dan meniupkan pada bagian tubuh yang terkena penyakit cacar.

\section{b. Mengobati Penyakit Eltor (Cika)}

Penyakit eltor dapat disebabkan oleh berbagai hal, di antaranya makanan yang kurang bersih. Contohnya air yang tidak direbus, makanan yang tidak ditutup karena mudah dihinggapi lalat sehingga membawa bermacam-macam bibit penyakit. Pada umumnya gejala penyakit eltor yaitu adanya keringat dingin, lemas, pucat, diare, mual-mual, dan lainnya. 
Cara meredam penyakit ini biasanya dengan memanfaatkan dedaunan yang tumbuh di sekitar rumah, misalnya meminum rebusan air beberapa lembar daun jambu muda. Campuran irisan bawang merah dengan irisan minyak kelapa digosokkan di daerah yang sakit. Bila penderita sulit buang angin (kentut) bisa diobati dengan campuran tembakau dengan minyak kayu putih atau minyak kelapa kemudian digosokkan di bagian perut.

Jika pertolongan pertama telah dilakukan tetapi belum sembuh masyarakat Makassar menggunakan doangang. Adapun doangang yang dibaca oleh dukun untuk mengobati penyakit eltor yang dalam bahasa Makassar disebut cika sebagai berikut.

\section{Bismillahirrahmanirrahim \\ Cika barikbasak allo \\ Cika tangngallo \\ Cika karueng allo \\ Assulukko antureng \\ Teako ammantangngi ri ... (arena tau garringa) \\ Barakkak la ilaha illallah \\ Barakkak ya Rasulullah \\ Terjemahan :}

Dengan nama Allah Tuhan Yang

Pengasih lagi Maha Penyayang

Cika yang menyerang diwaktu pagi

Cika siang hari

Cika di waktu sore

keluarlah dari situ

jangan tinggal di ....

(sebut nama orang yang sakit)

Berkat Muhammad ya Rasulullah

Cara pengobatan dengan menyediakan segelas air kemudian membaca doangang berulang-ulang minimal tiga kali, lalu ditiupkan dalam segelas air. Setelah itu, sebagian air diminum dan sisanya dioleskan pada bagian perut.

\section{c. Mengobati Penyakit Mata}

Apabila kita sedang bepergian, misalnya dengan mengendarai sepeda motor, sepeda, atau berjalan kaki, tidak mus-tahil mata kita kemasukan debu atau kelilipan. Kalau kotoran yang masuk pada mata kita tidak cepat diobati bisa mengakibatkan mata perih sakit, rabun, bahkan bisa buta. Oleh karena itu perlu untuk membersihkan mata dan mengobatinya. Adapun doangang yang khusus digunakan untuk membuang kotoran yang masuk dalam mata adalah sebagai berikut.

Bismillahirrahmanirrahim

Sariukjintu areng tojeng-tojengnu Ri Allah taala

Ri bokonako linoa ballaknu

Ri bangkenna langika butta Pattarawanngannu

Barakkak La Ilaha Illalllah Barakkak ya Rasulullah.

Terjemahannya :

Dengan nama Allah Tuhan Yang Maha Pengasih lagi Maha Penyayang

Sariuk namamu pada Tuhan Allah

Di luar langit tempatmu

Di kaki langit tempat kuburmu Berkat la Ilaha Illalla Berkat ya Rasulullah

Caranya, membuka kelopak mata yang kena kotoran atau tempelkan kain pada mata yang kena kotoran kemudian membacakan doangang dan tiupkan pada mata. Lakukan cara seperti ini secara berulang-ulang sebanyak tiga kali. 
Selanjutnya agar mata lebih bersih sebaiknya mata direndam sejam pada air bersih yang ditaruh dalam piring kaca putih. Lakukan cara ini secara berulang-ulang sambil mata digosokgosokkan dengan pelan-pelan sehingga mata terasa terang dan nyaman.

\section{d. Mengobati Penyakit Demam}

Apabila seseorang mengalami penyakit demam, maka orang Makassar yang berdomisili di pedalaman biasa meminta jasa para dukun untuk mengobatinya. Dukun atau sanro akan memberi air dengan membacakan doangang penawar sebagai berikut :

\section{Bismillahirrahmanirrahim}

Allahumma sholli Ala Muhammmad Wa Ala Ali Muhammad

Terjemahan :

Dengan nama Allah Tuhan Yang Maha Pengasih lagi Maha Penyayang

Segala puji bagi Allah yang

Mengutus atas Nabi Muhammad

Sallallahu Alaihi Wassalam.

Pelaksanaannya, dukun memberi air putih secukupnya kepada penderita demam. Air putih sebelumnya sudah diberi doangang oleh dukun. Air putih yang sudah diberi doangang harus diminum penderita. Selebihnya air putih diusapkan pada tubuh penderita hingga tidak tersisa. Doangang di atas biasanya di-baca oleh dukun secara berulangulang minimal tiga kali.

\section{e. Mencegah Gigitan Ular}

Beberapa jenis ular yang dikenal oleh orang Makassar, antara lain ular sawah, ular hitam (ularak lekleng), ular daun (ularak lekok), dan ular tanah. Beberapa jenis ular ada yang berbahaya. Bahkan tidak jarang orang yang digigit ular bisa meninggal dunia sebab racun berbisa.

Salah satu cara yang dilakukan oleh orang Makassar untuk mencegah gigitan ular adalah dengan membacakan doangang. Doangang yang digunakan itu berbunyi seperti berikut:

\section{Bismillahirrahmanirrahim}

I kau I pukrung arennu Palik-palili kalennu

Nanumaloi, tau akbulua Ulunna Terjemahannya :

Dengan nama Allah Tuhan Yang Maha Pengasih lagi Maha penyayang Engkau I Pukrung namamu Singkirkanlah dirimu Akan lewat, orang yang Serambut kepalanya.

Fungsi doangang di atas agar cepat sembuh dan tidak merasa sakit terhadap racun ular yang menyebar ke dalam tubuh. Cara pengobatan dengan dibacakan doangang satu kali kemudian tiupkan ke air putih di dalam gelas sebanyak tiga kali. Setelah itu diminum. Bisa juga membaca doangang tiga kali kemudian ditiupkan pada bagian tubuh yang digigit ular sebanyak tiga kali pula.

Selain itu doangang ini bisa sebagai penangkal ular (bahasa Makassar pallopu ularak). Apabila ada ular maka kita baca doangang sebanyak-banyaknya sambil menatap mata ular. Usahakan jangan berhenti membaca doangang meski ular tersebut masih kelihatan buas. Ular akan berangsur-angsur menjadi jinak dan ketika dipegang tidak akan menggigit lagi. 


\section{Pandangan Masyarakat Terhadap Doangang Makassar}

Dalam kehidupan sehari-hari di kalangan masyarakat awam dan sebagian kaum intelektual ada yang masih memakai doangang atau mantra yang diyakini dapat mengatasi semua persoalan dalam kehidupan. Doangang adalah ilmu yang dimiliki oleh orang tertentu yang diwariskan secara turuntemurun kepada orang yang berhak mewarisinya. Alasan mengatakan hal demikian karena masih banyak orang yang mengikatkan diri pada doangang ketika mengalami kesulitan, apakah itu petani, pedagang, pengusaha, dokter, polisi, dosen dan lainnya.

Faktor sebagaimana yang dipaparkan tersebut menandakan bahwa mantra masih diyakini oleh karena itu doangang harus dikembangkan dan dilestarikan secara turuntemurun, sebab doangang tidak dapat diberikan kepada yang tidak termasuk keturunannya, kalau tidak berhak maka doangang tersebut tidak bisa diwariskan.

Mewarisi suatu doangang harus memenuhi syarat-syarat tertentu yang mungkin menyulitkan bagi pewaris, tetapi kalau bisa melaksanakanya maka doangang tersebut berhak diwarisi. Bagi masyarakat yang setuju dibagi atas dua kelompok, yaitu: yang setuju melaksanakan dan yang setuju tetapi tidak melaksanakan. Bagi yang setuju melaksanakan, menganggap bahwa kehadiran doangang perlu untuk menghadapi masalah kehidupan yang semakin kompleks di jaman sekarang.
Sejumlah penilaian, sikap, dan perlakuan masyarakat terhadap doangang semakin berkembang. Sebagian masyarakat ada yang begitu mengikatkan secara penuh maupun sebagian dirinya terhadap doangang dalam kepentingan hidupnya seperti masih percaya pada mitos, pemenuhan kebutuhan sehari-hari, menghadapi persaingan, perlu untuk kenaikan pangkat, berharap disenangi atasan dan masih banyak lagi problema hidup yang menuntut harapan masyarakat kepada keampuhan mantra.

Sedangkan sebagian masyarakat yang setuju tetapi tidak melaksanakan secara langsung atau tidak langsung atau menolak kehadiran doangang dengan berbagai pertimbangan antara lain bahwa menerima doangang berarti melakukan perbuatan syirik, karena dipandang lebih yakin kepada dukun atau sanro daripada Allah, terlalu banyak kemauan yang harus dipenuhi yang persyaratnnya dirasa sangat sulit didapat dan membutuhkan waktu lama.

Pada bagian masyarakat yang disebutkan pertama dapat digolongkan ke dalam masyarakat penghayat atau pendukung doangang, sedangkan bagian masyarakat yang lainnya digolongkan ke dalam masyarakat bukan penghayat mantra.

Bagi masyarakat penghayat mantra, kegiatan sehari-hari kerap kali diwarnai dengan pembacaan mantra demi keberhasilan dalam mencapai maksud atau tujuan yang sesuai dengan fungsi dari mantra tersebut misalnya, para petani ingin sawahnya subur, terhindar dari 
gangguan hama, ingin panen hasilnya melimpah dan para pedagang ingin dagangannya laris.

Mantra diterima oleh masyarakat penghayatnya sebagai kebutuhan penunjang setelah kehidupan agamanya dijalani secara sungguh-sungguh. Adanya kebutuhan terhadap mantra sebagai warna yang menghiasi kehidupan sehari-hari dapat kita lihat pada setiap mantra diawali dengan bacaan Bismillahirrahmanirrahim dan diakhiri dengan kalimat La Ilaha illallah Muhammadarrasulullah, hal tersebut menandakan bahwa semua penyerahan permasalahan dan permintaan ditujukan pada Allah SWT. Kegiatan yang tidak terlepas kepada keadaan alam dan mata pencaharian, menghasilkan tiga kelompok besar sehubungan dengan penggunaan mantra, yaitu mantra yang digunakan untuk perlindungan, kekuatan, dan pengobatan (Rusyana, 1970).

\section{SIMPULAN}

Doangang atau mantra merupakan suatu adat istidat yang masih dipercayai oleh masyarakat penghayatnya sebagai kebutuhan penunjang setelah kehidupan agamanya dijalani secara sungguhsungguh. Adanya kebutuhan terhadap mantra sebagai warna yang menghiasi kehidupan sehari-hari.

Kegiatan tersebut tidak terlepas dari keadaan alam dan mata pencaharian, sehingga ada tiga jenis fungsi doangang atau mantra yaitu untuk perlindungan, kekuatan dan pengobatan. Masyarakat berpandangan tentang doangang atau mantra sebagai suatu karya yang di wariskan secara turun-temurun kepada orang yang berhak, karena tidak semua orang bisa melakukannya. Mantra merupakan suatu adat istidat yang masih dipercayai oleh masyarakat penghayatnya sebagai kebutuhan penunjang setelah kehidupan agamanya dijalani secara sungguh-sungguh.

Saran-saran (1) doangang sebagai salah satu produk budaya orang Makassar, perlu digali lebih dalam lagi sehingga fungsi dan kedudukannya di tengah-tengah masyarakat pendukungnya. (2) Perlu adanya penelitian lanjutan tentang doangang Makassar, disamping khasanah sastra lisan Makassar lainnya.

\section{DAFTAR SUMBER}

Aminuddin. 2011. Pengantar Apresiasi Karya Sastra. Bandung: Sinar Baru Algesindo.

Arikunto., S. 2006. Prosedur Penelitian Suatu Pendekatan Praktik. Jakarta: Rineka Cipta.

Damono, Supardi Djoko. 1987. Keterlibatan Sastra Indonesia; Kumpulan Karangan. Depok: Fakultas Sastra Universitas Indonesia.

Depdiknas. 2005. Kamus Besar Bahasa Indonesia. Edisi Ketiga. Jakarta: Balai Pustaka.

Endawarsa, S. 2008. Metodologi Penelitian Folklor, cet.1. Yogyakarta: Media Presindo. 
Hadi, S. 2004. Metodologi Research, ed. II. Yogyakarta : Andi Yogyakarta.

Ismail, Abdurachman. et al. 1996. Fungsi Mantra Dalam Masyarakat Banjar. Jakarta: Pusat Pembinaan dan Pengembangan Bahasa, Departemen Pendidikan dan Kebudayaan.

Nasruddin, 1997. Fungsi Doangang. Ujung Pandang: Departemen Pendidikan Kebudayaan Pusat Pembinaan dan Pengembangan Bahasa Balai Penelitian Bahasa Ujung Pandang.

Nurgiyantoro, B. 2009. Teori Pengkajian Fiksi. Yogyakarta: Gajah Mada Unity Press.

Nuruddin. 2007. Dasar-Dasar Penulisan. Mataram: Universitas Muhammadiyah Mataram.

Moleong, L. J. 2010. Metodologi Penelitian Kualitatif. Bandung: Remaja Rosdakarya.

Polak. J.B.A.F. Major. 1986. Sosiologi. Jakarta: Ichtiar.

Pradopo, R. J. 1995. Beberapa Teori Sastra, Metode Kritik, dan Penerapannya. Yogyakarta: Pustaka Pelajar.

Pudentia. MPSS (ed.). 2008. Metodologi Kajian Sastra Lisan. Jakarta: Asosiasi Tradisi Lisan.

Ratna, N. K. 2007. Estetika Sastra dan Budaya. Yoyakarta: Pustaka Pelajar.
Rusyana, Yus. 1970. Bagbagan Puisi Mantra Sunda. Bandung: Proyek Penelitian Pantun dan Folklore Sunda.

Suyasa, M. 2004. Teori Sastra. Mataram. Mataram: Universitas Muhammadiyah Mataram.

Syah, M. 2000. Psikologi Pendidikan dengan Pendekatan Baru. Bandung: Remaja Rosda Karya.

Tarigan, H. G. 1993. Prinsip-prinsip Dasar Sastra. Bandung: Angkasa.

Tjahjono, L. T. 1987. Sastra Indonesia Pengantar Teori dan Apresiasi. Surabaya: Nusa Indah.

Yatim, W. 1983. Genetika. Tarsito. Bandung. 